\title{
Social media, context collapse and the future of data-driven populism
}

\author{
Frederic Guerrero-Solé; Sara Suárez-Gonzalo; Cristòfol Rovira; Lluís Codina
}

Nota: Este artículo se puede leer en español en:

http://www.elprofesionaldelainformacion.com/contenidos/2020/sep/guerrero-suarez-rovira-codina_es.pdf

How to cite this article:

Guerrero-Solé, Frederic; Suárez-Gonzalo, Sara; Rovira, Cristòfol; Codina, Lluís (2020). "Social media, context collapse and the future of data-driven populism". Profesional de la información, v. 29, n. 5, e290506.

https://doi.org/10.3145/epi.2020.sep.06

Manuscript received on $30^{\text {th }}$ June 2020 Accepted on $11^{\text {th }}$ August 2020
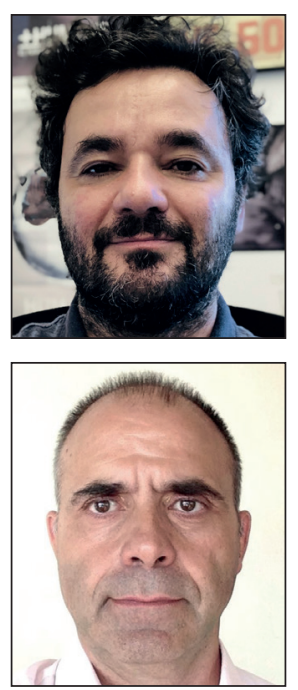

Frederic Guerrero-Solé

https://orcid.org/0000-0001-8145-8707

Universitat Pompeu Fabra

Departament de Comunicació

Roc Boronat, 138. 08018 Barcelona, Spain

frederic.guerrero@upf.edu

\section{Cristòfol Rovira}

https://orcid.org/0000-0002-6463-3216

Universitat Pompeu Fabra

Departament de Comunicació

Roc Boronat, 138. 08018 Barcelona, Spain

UPF Barcelona School of Management

Balmes, 134, 08008 Barcelona, Spain

cristofol.rovira@upf.edu
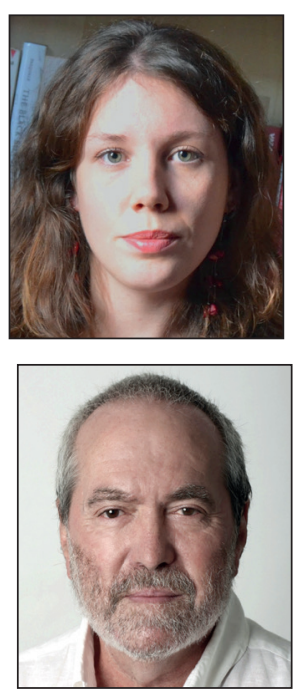

Sara Suárez-Gonzalo

https://orcid.org/0000-0001-6883-1984

Universitat Pompeu Fabra

Departament de Comunicació

Roc Boronat, 138. 08018 Barcelona, Spain

sarapaz.suarez@upf.edu

\section{Lluís Codina $\triangle$}

https://orcid.org/0000-0001-7020-1631

Universitat Pompeu Fabra

Departament de Comunicació

Roc Boronat, 138. 08018 Barcelona, Spain

UPF Barcelona School of Management

Balmes, 134, 08008 Barcelona, Spain

Iluis.codina@upf.edu

\begin{abstract}
During the last decades populism has become a mainstream ideology in Western democracies (Mudde, 2004; 2016). At the same time, the popularisation of digital platforms has facilitated the process of political communication while social networks have become one of the preferred communicative tools for political populists to spread their messages. Drawing on the idea that computational technologies allow a particular performance of populism (Baldwin-Philippi, 2019), this paper aims to foster a better theoretical understanding of how innovation in communication technologies contribute to the success of populism. It is argued that the characteristics of populism (a focus on 'the people', technological savviness and chameleonism) allow it to overcome most of the obstacles put in place by digital networks. In particular, populism is in an ideal situation to deal with the phenomena of context collapse in social media (Boyd; Marwick, 2011). Finally, it is argued that in the era of personalized politics (Bennett, 2012), populists can make use of real-time data-driven techniques to develop successful communicative strategies addressed to mass audiences in order to construct the populist self in the image and likeness of the people. This form of populism is called data-driven populism.
\end{abstract}

\section{Keywords}

Social media; Computational politics; Populism; Populist communication; Context collapse; Datafication; Microtargeting; Big data; Political communication.

\section{Funding}

This research was funded by the project "Polarization, duplication of active audiences and populism on Twitter. Analysis of the influence of populist discourses on political debates in Spain (2016-2020)" (Datapop). PGC2018097352-A-100 and "Interactive storytelling and digital visibility in interactive documentary and structured journalism”. RTI2018-095714-B-C21, ERDF and Ministry of Science, Innovation and Universities (Spain). 


\section{Introduction}

In the last two decades, populism has become a mainstream political ideology in Western democracies (Mudde, 2004; Rooduijn, 2014b; Casero-Ripollés; Sintes-Olivella; Franch, 2017). Although populism has existed since the $19^{\text {th }}$ century (Mazzoleni, 2014), it is precisely now that right-wing populist parties have achieved great popularity and electoral success in many European countries such as Italy, France and Austria (Mouffe, 2005), and more recently in Spain, Hungary, the UK and Brazil (Climent-Sanjuan; Montané-Goetzemberger, 2020; Shein, 2020; Putzel, 2020; Mudde, 2016; Alonso-Muñoz; Casero-Ripollés, 2018). Scholars have been analysing populist discourse for decades and have observed its roots in the emergence of mass societies which for some authors has given rise to populist democracies (Taggart, 2000). According to Kornhauser (1959), mass media are the cause, and not only the effect, of the rise of populism. Research has stressed the close relationship between media development and the rise and consolidation of populist forces. For instance, it has been said that the evolution of the media industry has provided an ideal environment for the growth of populism (Mudde, 2004). For Mazzoleni (2003) it compels researchers to analyse mass media properties to completely understand populism and populist discourses. Moreover, the evolution of media technologies and the popularization of social media have helped populism to develop itself free from many of the constraints of traditional mass media. In particular, social media have allowed populist parties to bypass media institutions and traditional gatekeepers (Engesser et al., 2017a) and have given it the possibility to communicate with citizens without mediation. Since the logics of mass media and network media are completely different in terms of production, distribution or media usage (Klinger; Svensson, 2015), it may be argued that with social media, populism has entered a new stage.

The popularization of social media has provided populist parties with an easy and affordable access to voters freed from the mediation of any other intervening actors, at human level by means of personalization and targeting like-minded others

The aim of this paper is to theoretically link two of the most well-known concepts of social networks communication, i.e., context collapse and imagined audiences, with the characteristics of populism and its technological performance (Baldwin-Philippi, 2019). It is argued that the often chameleonic, changeable and malleable nature of populist discourse (Taggart, 2000) finds its perfect environment in social media. On the other hand, in a context of disintermediated communication in which politicians have become responsible for their interactions with massive audiences (Bennett, 2012), populists can take advantage of real-time data-driven strategies to shape their messages and the way they represent themselves online by drawing on the shared characteristics of their audiences.

\section{Populism}

Scholars in political science hold that the frontiers between left and right have been blurred in Western democracies in the last decades (Mouffe, 2005). This context, in which differences between traditional parties weaken, combined with situations of crisis (Müller, 2016), are said to be a fertile ground for the emergence of so-called populist movements (Taggart, 2000; Mouffe, 2005). Populist discourse is an upward trend in the whole spectrum of political parties in Western countries and, for many scholars, it has become mainstream (Rooduijn, 2014a; Mudde, 2004). However, it expresses itself in a very fragmented way (Engesser et al., 2017a) and its characteristics are variable across countries and political cultures.

Even if there is no consensus on the definition of populism, many scholars have strived to discern the common traits of the diverse forms of populism. The centrality of a charismatic leader and the appeal to 'the people' against the ideological and economic elites, are some of the most common ones (Canovan, 1999). Differently, others, such as Elster (2020), hold that it is not possible to set out the "real" or "true" meaning of populism, nor to discover it through conceptual probes. Elster focuses on psychological attitudes and political programmes that define six types of populism: Lake Wobegon populism, short-termism, Trumpism, the attraction of simple solutions, responses to inequality, and direct democracy (Elster, 2020).

Populism has been widely considered to be a thin (Engesser et al., 2017b) and chameleonic political position (Taggart, 2000) and as a space created by post-industrial societies for less ideological parties that can combine diverse types of ideology (Mudde, 2004). It is framed as a political strategy aimed at constructing hegemony and power. Laclau and Mouffe are two of the most relevant theorists of populism in recent years. They pointed out the importance of the populist discourse, which is often ambiguous and fluctuating (Laclau, 2005) and always based on the construction of "the people" by bringing together multiple social demands (Laclau; Mouffe, 1987). The malleability of this concept of "the people", that can make reference to the (lower) social class, or appeal to the whole citizenship of a nation, is determinant in the construction of populist movements and hegemonies (Geffroy, 1989; Ruiz-Sanjuán, 2019). According to Müller's (2016) Seven theses on populism, populism is the permanent shadow of representative politics, given that there is always the possibility to speak

This paper discusses how populism can take advantage of the collapse of contexts in social media, and the contemporary data-driven social media analysis techniques 
in name of the "real people" facing powerful elites. Precisely, the symbolic representation of these real people allows populists to deduce the "correct" political position to adopt. Moreover, he considers populist actors to be anti-pluralist more than anti-elitist, and not necessarily favourable to a more participatory closer politics.

Others put the focus in distinguishing between right and left-wing populisms. In particular, Fraser (2017, p. 282), distinguishes into "reactionary" or "progressive" populist movements. According to her, populist movements are the consequence of a generalised rejection of the political establishments and both of the two types advocate for citizens' protection facing the problems that arise from globalisation and neoliberalism (Fraser, 2017). However, the main difference between the two stems from the fact that, while the first one explains these problems from an individualistic perspective and focuses on identifying and blaming culprits, often among minorities, the other puts the emphasis on the reversion of structural inequities and the need for social protection as means for emancipation.

When it comes to identifying the boundaries of populism, scholars have usually drawn on the basic elements of the populist discourse. Populist discourse is said to be simplistic and emotionally knotted (Taggart, 2000). It tries to reduce the complexity of reality (Engesser et al., 2017a), and it is, in general, ambiguous and malleable. Contrary to more ideologized parties with a dogmatic character, populist discourse is adjustable and adaptable (Rooduijn; De-Lange; Vander-Brug, 2014; Taggart, 2000). A majority of the studies on populist communication make use of content analysis to define what populism is. The general conclusions are that populist communication is centred on 'common people' and their traditional values and norms -the 'master frame' (Jagers; Walgrave, 2007), the heartland that becomes an imagined community that excludes the extreme (Taggart, 2000)-, and opposes 'the elite'. Mouffe (2005) also considers populism as an archaic form of identification that draws on the need for its followers to be a part of a community, the mythical construction of the heartland

The consequences of context collapse in social networks have been underexplored. In particular because of the difficulty in articulating a model for analysing what we call 'contexts'

(Mudde, 2004), since they may feel alienated, excluded or insecure (Reinemann et al., 2016). In particular, right and far-right populist discourses deal with anti-immigration (Alonso-Muñoz; Casero-Ripollés, 2018), anti-Islam, anti-EU, or anti-anything connected to a corrupt elite or a minority group that challenges common values or is opposed to the interest of an imagined homogeneous group of individuals. Finally, populist discourses also add narratives of crisis (Reinemann et al., 2016; Taggart, 2000). In sum, as proposed by Rooduijn (2014a), the common factors of populist discourse worldwide are; the central position of 'the people', criticism of elites, the consideration of 'the people' as a homogeneous entity and the existence of crisis.

\section{Populism and social media}

Scholars have also evinced the intimate link between populism and the development of mass media technologies. From a radically deterministic approach, Kornhauser (1959) considers populism as cause and effect within mass media society. In a similar vein, Mazzoleni (2007) asserts that it is precisely media complicity that has propitiated the presence of populist movements in the media. For the author, populist politicians are charismatic, master media strategists and adapt their discourse to the demands of commercial mass media and audiences. Their emotional treatment of social reality and their yielding to popular tastes and to the satisfaction of the audience make populists appealing for the mass media (Mazzoleni, 2007).

Populism has been studied in different media and formats such as television (Jagers; Walgrave, 2007), newspapers (Rooduijn, 2014a) or in party programs (Rooduijn; De-Lange; Van-der-Brug, 2014). However, the communicative dimension of populist politics has been underexplored (Aalberg; De-Vreese, 2016) and little attention has been paid to the technological performance of populism (Baldwin-Philippi, 2019). Nowadays, new communication technologies and in particular social networks have forced politicians to accommodate the logic of the new media (Mazzoleni, 2014). Populist politicians have incorporated social media networks into their communicative strategies. This intensive use of social media has had several consequences on populist discourse. Firstly, it has led to a more pronounced rhetoric: social media are thought to give more freedom to populists to attack elites (Klinger; Svensson, 2015) and therefore has facilitated anti-elite populism (Suiter et al., 2018). And secondly, social media communication has tended to be even more personal and emotional (Klinger; Svensson, 2015; Enli, 2017), in accordance with the aforementioned populist communication style.

Probably the most analysed fact related to the logic of new media is that of disintermediation (Aalberg; De-Vreese, 2016). Unmediated communication between politicians and citizens has a long tradition in political communication. One of the most outstanding works in this regard is that of Bimber (1998). Bimber forecasted the transformation of political communication resulting from the popularization of the internet among US citizens and the possibility of unmediated interaction between political institutions and citizens. For the author, the emergence of more independent media would allow people to be influenced not only by newsroom decisions, but also by information spread on the internet (Bimber, 1998). The popularization of social media has provided populist parties with new tools for interacting with the audiences. These environments allow politicians to circumvent media institutions and gatekeepers (Engesser et al., 2017a; Bracciale; Martella, 2017), and give populists new opportunities to spread their messages (Engesser et al., 2017b). Besides this, social networks, and Twitter in particular, are considered to be efficient and inexpensive platforms that provide 
an opportunity to afford a campaign to small political parties (Gainous; Wagner, 2014). In sum, parties now have an easy and affordable access to voters freed from the mediation of any other intervening actors, and communication with voters can be done at human level by means of personalization and targeting like-minded others (Engesser et al., 2017b).

However, Aalberg and De-Vreese (2016) argue that the study of the role of media in enabling the growth of populism has been based on overly simplistic views. Meanwhile, Krämer (2017) considers that the use of social media by populist parties has been generally neglected by researchers. What little research exists on this point has tended to focus on the rhetorical tools deployed by populists (Baldwin-Philippi, 2019). These approaches continue to view populism as a simplistic and static entity that can be defined by the use of words and concepts such as 'the people' or 'the elite.' However, populism adapts to new environments in many different ways. Bracciale and Martella (2017) have tried to go further in the identification of the characteristics of the populist communication in social media. They differentiate content (what is being said) and form (how it is being said), and define several indicators of the form, register, topics, and functions. These indicators lead them to define the main populist communication style on social media. However, their conclusions about the discursive characteristics of populism coincide with those of previous research: the populist communication style includes the defence of 'the people' against elites, the use of vulgar language exploiting anxieties and fears, the sharing of emotions and aspects of private lives, and audience engagement (Bracciale; Martella, 2017).

This paper discusses how populism can take advantage of the collapse of contexts in social media, and how contemporary data-driven social media analysis techniques can be a particular asset for populist parties to support the production of their messages far beyond the online microtargeting strategies used by other parties. This contribution assumes that, because of the objectives of populist parties and most of their characteristics, populist communication nowadays is primarily dynamic and obeys the changes observed in the attitudes and behaviours of the audiences, as well as to the nature of social media technologies. But unlike past populism, it is not only based on the construction of 'the people' on shared and common characteristics of its audience, but on its own construction of the image and likeness of 'the people'.

The authors acknowledge that nowadays, as mainstream media were in the past, social media are a fundamental means for social and political movements to have an influence on the public sphere (Gamson; Wolfsfeld, 1993). These authors describe the role played by media in mobilizing, legitimizing and widening the scope of social and political movements as media opportunity structure. Thus, social media are considered to play a critical role in the success of populism. However, it is without doubt that social media are not the necessary nor the sufficient condition that explains the success of populism in Western democracies. In particular, the whole political opportunity structure (Eisinger, 1973; Wahlström; Peterson, 2006), that is understood as the dimensions and the structural changes, such as demography or political economy that provide incentives to undertake collective actions (McAdam, 1982; Tarrow, 1994; Meyer; Minkoff, 2004), or the myriad of contexts, conditions and circumstances that can explain people's actions and the whole process of political persuasion. This paper is consequently focused in the part explained by media and communication as a factor that has an influence on the degree of political opportunity for a political movement to be successful (Cammaerts, 2012).

\section{Context collapse and imagined audiences}

Populist parties' communication strategies on social media have attracted the attention of scholars in recent years. However, as previously stated, research is often grounded in media content analysis without much consideration for the particular characteristics of social media platforms and their impact on populist strategies. Among these particular characteristics, the so-called context collapse stands out. Following Goffman's (1959) work on the analysis of social situations that have a strong influence on people's self-presentation and communication behavior, Meyrowitz (1985) introduced the concept of collapse when referring to the disappearance of any possible definition of a context in electronic media. The case of the American politician Stokely Carmichael served as an example to Meyrowitz to illustrate such collapse. Carmichael used to employ different communication styles when addressing black or white audiences, appearing authentic to both. But he was incapable of choosing between both styles when appearing on television because of the collapse of the two contexts. Additional work on context collapse has been continued by Boyd (2008; 2011), Boyd and Marwick (2011) and Marwick and Boyd (2011), all of which reflect on the obstacles for people to present themselves in different ways to different audiences at the same time (Veletsianos; Kimmons, 2016).

Being aware of the phenomenon of context collapse is of particular importance nowadays. In particular, because of its harmful consequences in environments such as social media, in which audiences can be considered almost infinite (Goffman, 1959). The more diverse the potential audience could be, the more tension for the sender of the message exists. For that reason, one of the main questions that scholars struggle to answer is what strategies do social media actors employ to minimize the impact of context collapse considering the lack of social, spatial or temporal boundaries (Duguay, 2016). Among the different strategies developed by social media actors to minimize the impact of contect collapse, we highlight:

- self-censorship,

- the creation of multiple identities (Boyd, 2008),

- the configuration of privacy settings,

- the encoding of messages so they can only be understood for the pretended audiences (Boyd; Marwick, 2011), and

- the maintenance of ambiguity through humor (Duguay, 2016). 
On the other hand, Davis and Jurgenson (2014) have proposed two strategies for users in relation to the multiple contexts that coexist in social networks:

- avoiding context collisions that could lead to negative outcomes, and

- promoting context collusion to gain engagement.

Context collusion means that actors intentionally flatten contexts (Duguay, 2016; Veletsianos; Kimmons, 2016). In this sense, Beam et al., (2017) confirm that when sharing online content, people are more likely to see this sharing as a context collusion rather than a context collision.

The consequences of context collapse in social networks have been underexplored. In particular because of the difficulty in articulating a model for analysing what we call 'contexts'. One of the constructs that help to model context collapse is that of the imagined audiences, a

'mental conceptualization of the people with whom we are communicating' (Litt, 2012).

In a face-to-face Goffmanian situation, the sender of a message can adapt his discourse to the receiver's expectations and shared social norms. However, electronic media blur such situations, and broadcasters must imagine what their audience is. Consequently, mediated communication forces people to imagine who their audience really is (Ross, 2011). The public nature of many of the messages makes it unthinkable that they are adapted for a potentially huge audience. Thus, the individual does everything possible so that his message meets the characteristics expected by his imagined audience.

The concept of imagined audiences brings the processes of production and reception closer (Espinosa, 1982). Research on the intimate relationship between production and reception has a long tradition in the field of communication research. In 1957, Gans already warned of the fundamental role of the image of the audience in the process of production. In a later study on film production in Hollywood, Espinosa (1982) found that producers' perceptions of the audience were of great importance in the production of scripts. In the same vein, Plesner (2012) found that the conception of citizens has an impact on the production of scientific knowledge. Ross (2011) proposes a more radical approach by considering that there should be no distinction between production and reception, since producers always have tacit knowledge of the audience and make use of imagined audiences in the creative process. For Ross (2011), producers often rely on experiences shared with members of the presumed audiences, and proposes a new model of production

"as a social situation sustained by participants but explicitly oriented to an absent third party: the audience" (Ross, 2011).

From a more critical approach, Mayer (2016) also noted that audience and production studies have been too separated in research. This separation does not allow scholars to reveal the power relations involved in the production process.

However, there is still a lack of satisfactory methodological approaches that deal with the way people imagine audiences and with the exploration of the factors that influence the construction of these imagined audiences (Litt, 2012). In particular, little research has been done on what people think about when posting on social media (Litt; Hargittai, 2016). Scholars have proposed several categorizations of imagined audiences but most of these studies draw on a simplistic conceptions of such audiences (Brake, 2009; Vitak, 2012) and reduce the characteristics of such audiences to groups, such as family, friends, peers, workmates or other people with shared interests (Veletsianos; Shaw, 2018). Litt and Hargittai (2016) proposed one of the more complete taxonomies by classifying imagined audiences into four groups, i.e., personal, communal, professional and phantasmal ties. Social media actors may also think about the audience when they spread a message and about the presumed situations in which the message will be read in future. Even more, if we consider the availability, persistence and archivability (Boyd, 2011) of the contents in social media, we should accept that these factors force people to think about present and future imagined contexts and audiences.

\section{Context collapse and real-time data-driven populism}

Past research on populism noted that populist politicians were more likely to accept technological changes to create new channels for the expression of people's opinions (Bell, 1992). On the other hand, technology has evolved in the direction of allowing political organizations to gather as much information about citizens as possible. Clemens (1983) points out the great influence of opinion polls on politicians and voters. Already in 1983, he foresaw the importance of technology innovation for political communication, and the power of almost instant communication between those governing and those governed thanks to the increase of the penetration of in-home telephones and the possibility to discuss in campaigns the results of telephone panels. Communication technology has dramatically evolved in the following four decades, and the datafication of people's interactions with and within platforms has expanded to almost every corner of social reality. The social introduction of social networks critically contributed to the growth of what Tufecki (2014) or Halavais (2015) have named big social media big data.

As pointed out by Couldry and Yu (2018), datafication must be considered as a natural stage in human development. In the context of technological development, politicians have expressed their wish to have tools to make sense of the information spread in social media and to look for citizen feedback and ideas (Stieglitz; Dang-Xuan, 2013). Thus, if past research stressed the absence for producers of cues provided by the audience (Thompson, 1995), today's technologies 
can furnish these producers with a huge quantity of data that characterize the receivers of their messages (Issenberg, 2012). In that sense, it cannot be said that in online mediated communication the audience is fully absent. On the contrary, nowadays politicians can make use of huge public and commercial databases with hundreds of millions of personal records (Hersh, 2015). By means of their hundreds of individual descriptive fields (Hersh, 2015), political parties can refine their microtargeting strategies and send a different message to every different member of the audience.

\section{Micro- versus macro-targetting strategies}

Online political microtargeting has attracted the attention of scholars in the last decade (Barocas, 2012). Data-driven field experiments for improving strategies and for choosing the winning message for a given target (Barocas, 2012) have boosted faith in computational methods to win elections (Issenberg, 2012). Targeting individuals to alter their behaviour has become the holy grail for politics (Tufekci, 2014). By means of data-analysis techniques, political parties can model and profile the public, and, consequently, optimize their tools aimed at persuading voters. These tools turn attention to the voter as the very target of canvassing. With this goal in mind, targeting analysts have developed powerful and accurate algorithms that make use of hundreds of personal and demographic variables combined with polling results (Couldry; Yu, 2018). These algorithms have proven to be very successful in predicting people's likelihood of voting for a candidate or in labelling them as shifters or undecided voters (Issenberg, 2012; Kabanov; Karyagin, 2018).

Targeting analysts have developed powerful and accurate algorithms that make use of hundreds of personal and demographic variables combined with polling results

Obama's campaigning in 2007 and the Facebook-Cambridge Analytica cases are the paradigmatic examples of the incorporation of these techniques to make decisions about the optimal way of representing the political candidates and constructing the electoral discourses (Gerbaudo, 2014; Groshek; Koc-Michalska, 2017; Kreis, 2017; Tufekci, 2014). However, Gold (2017) asserts that it was the massive use of data-driven techniques that was responsible for the Democrat failure in 2016. Conversely, Halpern (2017) considers that it was the use of targeting strategies on Facebook and Trump's analytical tool Battleground Optimizer Path to Victory that allowed him to win the presidency in 2016. The method developed by Kosinski, Stillwell and Graepel (2013) demonstrated the possibility of conducting psychometric studies, able to infer highly sensitive personal by automatically analysing people's "likes" on Facebook. This was the method which Cambridge Analytica used as part of a micro-targeting strategy to help Trump win the 2016 presidential elections of USA and the Leave vote in the Brexit referendum (Dutton et al., 2017; Suárez-Gonzalo, 2018).

In short, there is still an acute debate between those who believe that microtargeting is a useful tool for campaigning, and those who believe that microtargeting is useless while also being a threat to democracy (Hersh, 2015).

\section{Data-driven populism}

There are also discrepancies between whether microtargeting is a genuine populist approach for campaigning or not. For Baldwin-Philippi (2019), targeting voters shouldn't be considered as a populist strategy since it entails the segmentation of the audience into groups (Hersh, 2015) which in the process separates and disburses the pure and homogeneous 'people' who are at the very centre of populist discourse. On the contrary, populist politicians are more willing to choose mass-oriented strategies without targeting particular individuals or groups.

Microtargeting has been considered as a means for politicians and other media actors to overcome the harmful consequences of context collapse. However, it is not the only strategy for this purpose. Context collusion, the deliberate bringing together of multiple networks and contexts (Marwick; Boyd, 2011), can also be a convenient way of overcoming these consequences while it is precisely the populist political discourse that best meets the conditions for successful context collusion. Research in populism has revealed that one of the main characteristics of populist discourse is the permanent presence of common and shared values of a given social group. It is populism, and only populism, that represents the common people (Müller, 2016). Being so, a presumable strategy of those actors who feel threatened by context collapse is the use of what Hogan (2010) calls the lowest common denominator (or, in our view, the greatest common factor). This greatest common factor refers to the characteristics shared by a group of entities or networks and can be considered as a flawless strategy for context collusion. Consequently, populist politicians, and other social media actors choose to restrict content-sharing to messages that can be shared with all the members of the audience. According to other research, this is precisely the strategy followed by users who have a large quantity of contacts (Beam; Child; Hutchens; Hmielowski, 2017; Hogan, 2010; Litt, 2012) while the rest of the users tend to avoid this approach (Vitak, 2012; Sibona, 2014). Consequently, we argue that social networks are the perfect environment for populist parties to spread their message because context collapse is innocuous for political ideologies based on the shared.

Obama's campaigning in 2007 and the Facebook-Cambridge Analytica cases are the paradigmatic examples of the incorporation of data-driven techniques to make decisions about the optimal way of representing the political candidates and constructing the electoral discourses 
This is not to say, in any sense, that populism doesn't take advantage of the datafication of people's interactions on technological platforms. The argument here is that it is in a better position than the other ideologies to complement their strategies with those based on context collusion. As producers of political discourses, populist politicians can also make the most of the capabilities offered by social media technologies to obtain relevant information about the audience. While it is still possible that the producers of media messages are not always interested in analyzing the characteristics of their audience (Ross, 2014), and they prefer to rely on their own perceptions and presumptions about the public (Brake, 2009), politicians, and in particular populist ones, cannot rely on these presumptions. Technology offers them the tools for analyzing in real-time people's opinions, attitudes and behaviors with regard to any kind of issue. As it has been previously said, populism and only populism represents 'the people' (Müller, 2016). But 'the people' is as ambiguous and malleable as populism itself. For that reason, it is argued here that populism can take advantage of computational politics by obtaining improved and enriched images of this people and converge these imagined audiences with real ones. By using highly sophisticated techniques such as social media listening and social network analysis (Wilkers; Casas, 2017; Álvarez, 2016), populist (and not populist) politicians can have relevant information about the composition of their audiences. But computational politics allows, not only an individual profiling of the voters, but a deep understanding of what these voters share at all times. In this sense, populism and 'the people' converge dynamically, a process that is in tune with populism's optimism about changeability and its chameleonic and malleable nature.

Having reviewed the main treats of populism, in particular chameleonism, malleability and its focus on the shared (the people), the characteristics and harmful consequences of context collapse, and the use of the imagined audiences to shape the discourse and adapt it to the target, we propose an operative definition of data-driven populism as follows:

Data-driven populism is a form of populism that finds its ideal environment in social networks and that makes use of network analytics to create, shape and adapt in real-time its discourse to the most common shared beliefs, attitudes and behaviours of the audience. This kind of populism pursues the objective of maximizing its impact, overcoming the harmful consequences of the context collapse, and presenting a homogeneous image of itself and its audience, the people. Consequently, data-driven populism is based in the technological construction of a perfect replica of its audience.

\section{Discussion}

Digital technologies have radically changed the way humans communicate and interact. Social media platforms have allowed the disintermediation of communication. This process has particularly affected political communication. Politicians can nowadays circumvent media outlets (Engesser et al., 2017a; Bracciale; Martella, 2017) and establish a direct connection between themselves and their voters. But this change has also led to a massive datafication of everyday interactions that are carried out within digital platforms and to the emergence of data and computational politics analysts as key actors in the definition and execution of political discourses and canvassing. A myriad of companies specialized in raw data and black-box algorithms has flourished around the industry of winning votes (Issenberg, 2012). Within this context, microtargeting strategies have been considered as the holy grail and the definitive weapon for winning elections in modern democracies (Hersh, 2015). Enli and Skogerb $\varnothing$ (2013) consider that politicians' strategies may become more targeted and elitist, trying to appeal the interest of particular people rather than of everybody. This enthusiasm has been bolstered by the narratives of success in the use of computational and experimental political machinery to persuade voters and predict changes in rates of support for candidates (Issenberg, 2012). Nowadays, data-driven canvassing and decision-making are so interwoven with candidates that their behaviour is constantly changing, to the point that they can even decide to redirect their plans to target areas (Hersh, 2015) drawing on the results of their data analysis. Social media big data, in combination with polling results, public databases and psychographics, have allowed the improvement in audience profiling, and have made the dream of a personalized message for every voter come true.

However, such optimism in microtargeting has been questioned by scholars. In particular, it has been said that microtargeting distorts politicians' perceptions and voters' attitudes by limiting their exposure to alternative political viewpoints (Issenberg, 2012). In the same vein, Beam et al. (2017) consider that microtargeting, combined with platforms' algorithms, lead to the formation of filter bubbles and echo chambers that pose new challenges for democracy.

The challenges posed by datafication and computational politics including the threats to personal privacy and surveillance have been accompanied by the rise of populism in Western societies. As with other ideologies, populism has taken advantage of the new capabilities provided by digital platforms and big data techniques. But, as it has been argued in this paper, the characteristics of populism allow it to overcome most of the difficulties posed by the nature of disintermediated communication differently than other ideologies do. In particular, while microtargeting can be considered as an optimal tool for liberalism which believes in intrinsic individuality and uniqueness of the voter, populism can make use of other complementary strategies to avoid the harmful effects of context collapse in digital media (Boyd; Marwick, 2011). These strategies are based on the core characteristics of populism, such as the construction of 'the people', its chameleonism or its ambiguity. Thus, since populism is 'the people' talking to 'the people' about 'the people', it is immune to the harmful consequences of context collusion. 
Consequently, we have argued that more than talking about or constructing 'the people', by means of sophisticated computational technologies (Wilkers; Casas, 2017) today's data-driven populism becomes 'the people'. Social media analysis allows populism to dynamically access voters' perceptions and attitudes (Hersh, 2015) in regards to a given issue, and to adapt its strategies to the satisfaction of these voters (Mazzoleni, 2007) and to popular tastes. The analysis of the greatest common factors is the guarantee of the lowest risk in making opinions public under the threat of context collapse. In this sense, datafication and the knowledge obtained from public and commercial databases is not oriented to the personalization of the message, but to the dynamic definition of social situations (Goffman, 1959; Ross, 2014) in which the communication process between the populists and the whole audience will take place, as well as the construction of the populist self. This populist self entails constant redefinition of how populism presents itself according to the expectations and the characteristics of audiences. It is in tune with its thinness and chameleonism (Taggart, 2000; Engesser et al., 2017b) and leads to a radical and definitive change in our conception of ideology. Populist technological performance (Baldwin-Philippi, 2019) releases the populist self from axioms, precepts or dogmas, and attunes its messages to audiences.

Although populism can also make use of microtargeting strategies for persuading its audiences, a radical approach to populism can consider these strategies as something undesired or impure. Populism is essentially moralistic (Mudde, 2004), and conceives 'the people' as homogeneous, uniform, and as something that cannot be degraded to the sum of its individual components. Consequently, a form of populism that demonizes the use of sophisticated technologies for targeting individuals would syntonise not only with its conception of the people, but also with the nature of its anti-elite and anti-complexity sentiment.

\section{Conclusion}

Scholars have linked populism with the development of mass media technologies (Kornhauser, 1959; Aalberg; De-Vreese, 2016). The current rise of right-wing populist parties in many countries worldwide has coincide in time with the popularization of social media as a new technological means for politicians to communicate with citizens without the intervention of traditional media. We have argued that social media intensify the process of context collapse (Boyd, 2008; Boyd, 2011; Litt, 2012) first described by Meyrowitz (1985). As a consequence, populist communication, based on the construction of 'the people' and on the shared characteristics of massive audiences, can better adapt to these environments and avoid the reported harmful consequences of context collapse -that are circumvented by non-populist parties by means of microtargeting strategies-. Populists' imagined audiences are, therefore, consequential with their master frame (Jagers; Walgrave, 2007), the broad and imagined community that excludes the extreme (Taggart, 2000). In short, communication and political science should consider that one of the present technological performances of populism is to dynamically adapt to the shared characteristics of broad audiences by using data-driven techniques. Unlike other parties, populist do not need to use microtargeting strategies that distort voters' attitudes and can eventually lead to the formation of echo chambers, and are not in tune with its homogeneous and uniform people (Mudde, 2004) that cannot be demeaned to the sum of individual components. In sum, a new form of populism, that we have called data-driven populism, is emerging or can emerge in the future thanks to its ability to adapt to social media and new digital environments.

In sum, this paper contributes to the theoretical debate about the new technological performances of politics that take advantage of big social data analytics to shape their political discourse. In particular, we conceptualize a new form of populism, that we call data-driven populism. It is defined by its use of network analysis to obtain the greatest common factors of the social media audience with the purpose of overcoming the negative consequences of context collapse. For future research, we propose the development of a method to analyze data-driven discourses, based on the conceptual grounds set out in this work.

\section{References}

Aalberg, Toril; De-Vreese, Claes H. (2016). "Introduction: Comprehending populist political communication". Populist political communication in Europe, pp. 3-11. ISBN: 9781315623016 https://doi.org/10.4324/9781315623016

Alonso-Muñoz, Laura; Casero-Ripollés, Andreu (2018). “Communication of European populist leaders on Twitter: Agenda setting and the 'more is less' effect". El profesional de la información, v. 27, n. 6, pp. 1193-1202.

https://doi.org/10.3145/epi.2018.nov.03

Álvarez, R. Michael (2016). Computational social science. Discovery and prediction. Cambridge: Cambridge University Press.

Baldwin-Philippi, Jessica (2019). “The technological performance of populism”. New media \& society, v. 21, n. 2, pp. $376-397$. https://doi.org/10.1177/1461444818797591

Barocas, Solon (2012). "The price of precision: Voter microtargeting and its potential harms to the democratic process". In: Proceedings of the First edition workshop on politics, elections and data, pp. 31-36. https://doi.org/10.1145/2389661.2389671

Beam, Michael A.; Child, Jeffrey T.; Hutchens, Myiah J.; Hmielowski, Jay D. (2017). "Context collapse and privacy management: Diversity in Facebook friends increases online news reading and sharing". New media \& society, v. 20, n. 7 , pp. 2296-2314.

https://doi.org/10.1177/1461444817714790 
Bell, Jeffrey (1992). Populism and elitism. Washington DC: Regnery Gateway. ISBN: 9780895265173

Bennett, W. Lance (2012). "The personalization of politics: Political identity, social media, and changing patterns of participation". Annals of the American Academy of Political and Social Science, v. 644, n. 1, pp. 20-39.

https://doi.org/10.1177/0002716212451428

Bimber, Bruce (1998). "The Internet and political transformation: Populism, community, and accelerated pluralism". Polity, v. 31, n. 1, pp. 133-160.

https://doi.org/10.2307/3235370

Boyd, Danah (2008). Taken out of context: American teen sociality in networked publics. PhD thesis. https://doi.org/10.2139/ssrn.1344756

Boyd, Danah (2011). "Social network sites as networked publics: affordances, dynamics, and implications". In: Papacharissi, Zizi (ed.) A networked self: Identity, community, and culture on social network sites. New York and London: Routledge, pp. 39-58.

https://doi.org/10.1177/1461444810365313

Boyd, Danah; Marwick, Alice (2011). "Social steganography: privacy in networked publics". In: 61 ${ }^{\text {st }}$ Annual ICA conference, Boston, MA, 26-30.

http://www.Danah.org/papers/2011/Steganography-ICAVersion.pdf

Bracciale, Roberta; Martella, Antonio (2017). "Define the populist political communication style: the case of Italian political leaders on Twitter". Information communication and society, v. 20, n. 9, pp. 1310-1329.

https://doi.org/10.1080/1369118X.2017.1328522

Brake, David R. (2009). As if nobody's reading?: The imagined audience and socio-technical biases in personal blogging practice in the UK. PhD thesis.

http://etheses.Ise.ac.uk/4/1/Brake_As_If_Nobodys_Reading.pdf

Cammaerts, Bart (2012). "Protest logics and the mediation opportunity structure". European journal of communication, v. 27, n. 2, pp. 117-134.

https://doi.org/10.1177/0267323112441007

Canovan, Margaret (1999). "Trust the people! Populism and the two faces of democracy". Political studies, v. 47, n. 1, pp. 2-26. https://doi.org/10.1111/1467-9248.00184

Casero-Ripollés, Andreu; Sintes-Olivella, Marçal; Franch, Pere (2017). "The populist political communication style in action: Podemos's issues and functions on Twitter during the 2016 Spanish general election". American behavioral scientist, v. 61, n. 9, pp. 986-1001.

https://doi.org/10.1177/0002764217707624

Clemens, John (1983). Polls, politics and populism. Hampshire, England: Gower Publishing Company.

Climent-Sanjuan, Víctor; Montané Goetzemberger, Miriam (2020). "The far-right populist parties in Spain: A comparative sociological analysis". Izquierdas, v. 49, pp. 910-931.

http://hdl.handle.net/2445/136757

Couldry, Nick; Yu, Jun (2018). “Deconstructing datafication's brave new world”. New media \& society, v. 20, n. 12, pp. $4473-4491$. https://doi.org/10.1177/1461444818775968

Davis, Jenny L.; Jurgenson, Nathan (2014). "Context collapse: Theorizing context collusions and collisions". Information communication and society, v. 17, n. 4, pp. 476-485.

https://doi.org/10.1080/1369118X.2014.888458

Duguay, Stefanie (2016). "'He has a way gayer Facebook than I do': Investigating sexual identity disclosure and context collapse on a social networking site". New media \& society, v. 18, n. 6, pp. 891-907.

https://doi.org/10.1177/1461444814549930

Dutton, William H.; Reisdorf, Bianca; Dubois, Elisabeth; Blank, Grant (2017). "Social shaping of the politics of internet search and networking: Moving beyond filter bubbles, echo chambers, and fake news". Quello Center working paper No. 2944191, pp. 1-26. https://doi.org/10.2139/ssrn.2944191

https://papers.ssrn.com/sol3/papers.cfm?abstract_id=2944191

Elster, Jon (2020). “Some notes on 'Populism'”. Philosophy and social criticism, v. 46, n. 5, pp. 591-600.

https://doi.org/10.1177/0191453720903773

Engesser, Sven; Ernst, Nicole; Esser, Frank; Büchel, Florin (2017a). "Populism and social media: how politicians spread a fragmented ideology". Information communication and society, v. 20, n. 8, pp. 1109-1126.

https://doi.org/10.1080/1369118X.2016.1207697 
Engesser, Sven; Ernst, Nicole; Esser, Frank; Büchel, Florin (2017b). “Extreme parties and populism: an analysis of Facebook and Twitter across six countries". Information, communication and society, v. 20, n. 9, pp. 1347-1364. https://doi.org/10.1080/1369118X.2017.1329333

Enli, Gunn (2017). "Twitter as arena for the authentic outsider: Exploring the social media campaigns of Trump and Clinton in the 2016 US presidential election". European journal of communication, v. 32, n. 1, pp. 50-61. https://www.duo.uio.no/bitstream/handle/10852/55266/2/Twitter_as_arena_for_the_authentic_outsi.pdf https://doi.org/10.1177/0267323116682802

Enli, Gunn; Skogerbø, Eli (2013). “Personalized campaigns in party-centred politics: Twitter and Facebook as arenas for political communication". Information, communication \& society, v. 16, n. 5, pp. 757-774. https://doi.org/10.1080/1369118X.2013.782330

Espinosa, Paul (1982). "The audience in the text: Ethnographic observations of a Hollywood story conference". Media, culture \& society, v. 4, n. 1, pp. 77-86. https://doi.org/10.1177/016344378200400107

Fraser, Nancy (2017). "Progressive neoliberalism versus reactionary populism: A choice that feminists should refuse". NORA. Nordic journal of feminist and gender research, v. 24, n. 4, pp. 281-284. https://doi.org/10.1080/08038740.2016.1278263

Gainous, Jason; Wagner, Kevin M. (2014). Tweeting to power: The social media revolution in American politics. New York, NY: Oxford University Press.

Gamson, William A.; Wolfsfeld, Gadi (1993). "Movements and media as interacting systems". Annals of the American Academy of Political and Social Science, v. 528, Citizens, protest, and democracy, pp. 114-127. https://doi.org/10.2307/1047795

Geffroy, Annie (1989). “Le peuple selon Robespierre". In: AA. VV.: Permanences de la Révolution: pour un autre bicentenaire, Montreuil: La Brèche-PEC, pp. 179-193.

Gerbaudo, Paolo (2014). "Populism 2.0: social media activism, the generic Internet user and interactive direct democracy". In: Trottier, D.; Fuchs, C. (eds.) Social media, politics and the state: Protests, revolutions, riots, crime and policing in the age of Facebook, Twitter and Youtube. New York: Routledge, pp. 67-87

Goffman, Erving (1959). The presentation of self in everyday life. London: Penguin Books.

Gold, Dave (2017). "Data-driven" campaigns are killing the democratic party. Politico magazine, February 9. http://politi.co/2krhUuC

Groshek, Jacob; Koc-Michalska, Karolina (2017). “Helping populism win? Social media use, filter bubbles, and support for populist presidential candidates in the 2016 US election campaign. Information, communication \& society, v. 20, pp. 1389-1407. https://doi.org/10.1080/1369118X.2017.1329334

Halavais, Alexander (2015). "Bigger sociological imaginations: Framing big social data theory and methods". Information, communication \& society, v. 18, n. 5, pp. 583-594.

https://doi.org/10.1080/1369118X.2015.1008543

Halpern, Sue (2017). "How he used Facebook to win". The New York review of books. https://www.nybooks.com/articles/2017/06/08/how-trump-used-facebook-to-win

Hersh, Eitan D. (2015). Hacking the electorate: How campaigns perceive voters. New York: Cambridge University Press.

Hogan, Bernie (2010). "The presentation of self in the age of social media: Distinguishing performances and exhibitions online". Bulletin of science, technology \& society, v. 30, n. 6, pp. 377-386.

https://doi.org/10.1177/0270467610385893

Issenberg, Sasha (2012). The victory lab. The secret science of winning campaigns. New York: Crown.

Jagers, Jan; Walgrave, Stefaan (2007). "Populism as political communication style: An empirical study of political parties' discourse in Belgium". European journal of political research, v. 46, n. 3, pp. 319-345.

https://doi.org/10.1111/j.1475-6765.2006.00690.x

Kabanov, Yury; Karyagin, Maryagin (2018). "Data-driven authoritarianism: Non-democracies and big data". In: Alexandrov, Daniel A.; Boukhanovsky Alexander V.; Chugunov Andrei V.; Kabanov Yury; Koltsova Olessia (eds.). Digital transformation and global society. DTGS 2018. Communications in computer and information science, v. 858. https://doi.org/10.1007/978-3-030-02843-5_12

Klinger, Ulrike; Svensson, Jakob (2015). "The emergence of network media logic in political communication: A theoretical approach". New media and society, v. 17, n. 8, pp. 1241-1257.

https://doi.org/10.1177/1461444814522952 
Kornhauser, William (1959). The politics of mass society. Glencoe, Illinois: The Free Press.

Kosinski, Michal; Stillwell, David; Graepel, Tore (2013). "Private traits and attributes are predictable from digital records of human behavior". Proceedings of the National Academy of Sciences of the United States of America, v. 110, n. 15, pp. 5802-5805. https://doi.org/10.1073/pnas.1218772110

Krämer, Benjamin (2017). "Populist online practices: the function of the Internet in right-wing populism". Information communication and society, v. 20, n. 9, pp. 1293-1309.

https://doi.org/10.1080/1369118X.2017.1328520

Kreis, Ramona (2017). “The 'tweet politics' of president Trump". Journal of language and politics, v. 16, n. 4, pp. 607-618. https://doi.org/10.1075/jlp.17032.kre

Laclau, Ernesto (2005). La razón populista. Buenos Aires: Fondo de Cultura Económica.

Laclau, Ernesto; Mouffe, Chantal (1987). Hegemonía y estrategia socialista. Hacia una radicalización de la democracia. Madrid: Siglo XXI.

Litt, Eden (2012). “Knock, knock, who's there? The imagined audience”. Journal of broadcasting and electronic media, v. 56, n. 3, pp. 330-345.

https://doi.org/10.1080/08838151.2012.705195

Litt, Eden; Hargittai, Eszter (2016). "The imagined audience on social network sites". Social media and society, v. 2 , n. 1. https://doi.org/10.1177/2056305116633482

Marwick, Alice E.; Boyd, Danah (2011). "I tweet honestly, I tweet passionately: Twitter users, context collapse, and the imagined audience". New media and society, v. 13, n. 1, pp. 114-133.

Mayer, Vicki (2016). "The places where audience studies and production studies meet". Television and new media, v. 17, n. 8, pp. 706-718.

https://doi.org/10.1177/1527476416652482

Mazzoleni, Gianpietro (2003). "The media and the growth of neo-populism in contemporary democracies". In: G. Mazzoleni, J. Stewart and B. Horsfield (eds.). The media and neo-populism: A contemporary comparative analysis. London: Praeger, pp. 1-21.

Mazzoleni, Gianpietro (2007). "Populism and the media". In: Twenty-first century populism: The spectre of Western European democracy. Springer, pp. 49-64.

Mazzoleni, Gianpietro (2014). “Mediatization and political populism”. In: Esser, F. and Strömbäck, J. (eds.). Mediatization of politics. Basingstoke: Palgrave Macmillan, pp. 42-56.

https://doi.org/10.1057/97811372758

McAdam, Doug (1982). Political process and the development of black insurgency, 1930-1970. Chicago, IL: University of Chicago Press.

Meyer, David S.; Minkoff, Debra C. (2004). “Conceptualizing political opportunity”. Social forces, v. 82, n. 4, pp. $1457-1492$. https://doi.org/10.1353/sof.2004.0082

Meyrowitz, Joshua (1985). No sense of place: The impact of electronic media on social behavior. Oxford: Oxford University Press.

Mouffe, Chantal (2005). On the political. Thinking in action. London and New York: Routledge.

Mudde, Cas (2016). "Europe's populist surge: A long time in the making". Foreign affairs, n. 95, pp. 25-30.

https://www.foreignaffairs.com/articles/europe/2016-10-17/europe-s-populist-surge

Mudde, Cas (2004). "The populist Zeitgeist". Government and opposition, v. 39, n. 4, pp. 542-563.

https://doi.org/10.1111/j.1477-7053.2004.00135.x

Müller, Jan-Werner (2016). What is populism? Philadelphia: University of Pennsylvania Press.

Plesner, Ursula (2012). "When citizens matter in the mass mediation of science: The role of imagined audiences in multidirectional communication processes". In: Louise Phillips; Anabela Carvalho; Julie Doyle (eds.). Citizen voices: Performing public participation in science and environment communication, pp. 21-46. Bristol: Intellect. European Communication Research and Education Association Series.

Putzel, James (2020). "The 'populist' right challenge to neoliberalism: Social policy between a rock and a hard place". Development and change, v. 51, n. 2, pp. 418-441.

https://doi.org/10.1111/dech.12578

Reinemann, Carsten; Aalberg, Toril; Esser, Frank; Strömbäck, Jesper; De-Vreese, Claes H. (2016). "Populist political communication: Toward a model of its causes, forms, and effects". In: Toril Aalberg; Frank Esser; Carten Reinamann; Jesper Strömbäck; Claes H. De-Vreese (eds.). Populist political communication in Europe, pp. 12-25. ISBN: 9781138614826 
Rooduijn, Matthijs (2014a). "The mesmerizing message: The diffusion of populism in public debates in western European media". Political studies, v. 62, n. 4, pp. 726-744.

https://doi.org/10.1111/1467-9248.12074

Rooduijn, Matthijs (2014b). "The nucleus of populism: In search of the lowest common denominator". Government and opposition, v. 49, pp. 573-599.

https://doi.org/10.1017/gov.2013.30

Rooduijn, Matthijs; De-Lange, Sarah L.; Van-der-Brug, Wouter (2014). "A populist Zeitgeist? Programmatic contagion by populist parties in Western Europe". Party politics, v. 20, n. 4, pp. 563-575.

https://doi.org/10.1177/1354068811436065

Ross, Philippe (2011). "Is there an expertise of production? The case of new media producers". New media \& society, v. 13, n. 6, pp. 912-928.

https://doi.org/10.1177/1461444810385393

Ross, Philippe (2014). "Were producers and audiences ever separate? conceptualizing media production as social situation". Television and new media, v. 15, n. 2, pp. 157-174.

https://doi.org/10.1177/1527476412454686

Ruiz-Sanjuan, César (2019). Perspectivas del populismo. Cenaltes Ediciones: Viña del Mar.

Shein, Sergey (2020). "The role of conservatism in the development of right-wing populism in Europe: The UK case". World economy and international relations, v. 64, n. 2, pp. 34-41.

https://doi.org/10.20542/0131-2227-2020-64-2-34-41

Sibona, Christopher (2014). "Unfriending on Facebook: Context collapse and unfriending behaviors". In: Proceedings of the Annual Hawaii international conference on system sciences, pp. 1676-1685.

https://doi.org/10.1109/HICSS.2014.214

Stieglitz, Stefan; Dang-Xuan, Linh (2013). "Social media and political communication: a social media analytics framework". Social network analysis and mining, v. 3, n. 4, pp. 1277-1291.

https://doi.org/10.1007/s13278-012-0079-3

Suárez-Gonzalo, Sara (2018). "Your likes, your vote? Big personal data exploitation and media manipulation in the US presidential election campaign of Donald Trump in 2016". Quaderns del CAC, v. 21, n. July 2018, pp. 25-33.

https://www.cac.cat/sites/default/files/2019-01/Q44_Suarez_EN_1.pdf

Suiter, Jane; Culloty, Eileen; Greene, Derek; Siapera, Eugenia (2018). “Hybrid media and populist currents in Ireland's 2016 general election". European journal of communication, v. 33, n. 4, pp. 396-412.

https://doi.org/10.1177/0267323118775297

Taggart, Paul (2000). Populism. Buckingham: Open University Press.

Tarrow, Sidney (1994). Power in movement: Social movements and contentious politics. Cambridge: Cambridge University Press.

Thompson, John B. (1995). The media and modernity: A social theory of the media. Cambridge, UK. Polity.

Tufekci, Zeynep (2014). "Big questions for social media big data: Representativeness, validity and other methodological pitfalls". Proceedings of the $8^{\text {th }}$ Intl AAAl Conference on weblogs and social media.

https://www.aaai.org/ocs/index.php/ICWSM/ICWSM14/paper/viewFile/8062/8151

Veletsianos, George; Kimmons, Royce (2016). "Scholars in an increasingly open and digital world: How do education professors and students use Twitter?". Internet and higher education, v. 30, pp. 1-10.

https://doi.org/10.1016/j.iheduc.2016.02.002

Veletsianos, George; Shaw, Ashley (2018). "Scholars in an increasingly open and digital world: imagined audiences and their impact on scholars' online participation". Learning, media and technology, v. 43, n. 1, pp. 17-30.

https://doi.org/10.1080/17439884.2017.1305966

Vitak, Jessica (2012). "The impact of context collapse and privacy on social network site disclosures". Journal of broadcasting and electronic media, v. 56, n. 4, pp. 451-470.

https://doi.org/10.1080/08838151.2012.732140

Wahlström, Mattias; Peterson, Abby (2006). "Between the state and the market: Expanding the concept of 'political opportunity structure'". Acta sociologica, v. 49, n. 4, pp. 363-377.

https://doi.org/10.1177/0001699306071677

Wilkers, John; Casas, Andreu (2017). “Large-scale computerized text analysis in political science: Opportunities and challenges". Annual review of political science, v. 20, n. 1, pp. 529-544.

https://doi.org/10.1146/annurev-polisci-052615-025542 